\title{
LETTER
}

\section{A Contiguous High-resolution Radiation Hybrid Map of 44 Loci from the Distal Portion of the Long Arm of Human Chromosome 5}

\author{
Janet A. Warrington ${ }^{1}$ and John J. Wasmuth \\ Department of Biological Chemistry, College of Medicine, University of California, \\ Irvine, California 92717
}

\begin{abstract}
A contiguous high-resolution map of 44 loci from a $35-\mathrm{Mb}$ portion of the distal region of the long arm of human chromosome 5, q21-q35, was produced using radiation hybrid (RH) mapping in conjunction with a natural deletion mapping panel. The map includes 30 genes, four sequence-tagged site (STS) loci, and 10 DNA markers. Newly mapped markers fill two gap regions that were present in previous maps, between markers FER-IL4 and IL3-IL9. Identifying the position of genes on the physical map aids in positional cloning efforts and contributes to our understanding of the overall organization of the human genome.
\end{abstract}

The distal region of the long arm of human chromosome 5 has been identified as the site of many disease genes including diastrophic dysplasia, Treacher Collins syndrome, hyperekplexia, an autosomal dominant form of limb girdle muscular dystrophy, familial adenomatous polyposis coli, acute lymphocytic leukemia, acute nonlymphocytic leukemia, $5 \mathrm{q}$ deletion syndrome, myelodysplastic syndrome, nonsyndromic autosomal-dominant deafness, and Boston-type craniosynostosis (Huebner et al. 1985; Le Beau et al. 1986, 1987; Sutherland et al. 1988; Grimaldi and Meeker 1989; Hästbacka et al. 1990; Groden et al. 1991; Jabs et al. 1991; Joslyn et al. 1991; Kinzler et al. 1991; Nishisho et al. 1991; Leon et al. 1992; Ryan et al. 1992a; Speer et al. 1992; Muller et al. 1993; Shiang et al. 1993; The Treacher Collins Syndrome Collaborative Group 1996). The order of and distance between 44 loci from an $\sim 35-\mathrm{Mb}$ portion of the distal region of the long arm of chromosome 5, spanning the cytogenetic region $5 q 21-5 q 35$, has been determined by radiation hybrid (RH) mapping. Previous work using RH mapping in conjunction with a natural deletion mapping panel determined the order of and relative distance between 13, 18, and 12 loci, respectively (Warrington et al. 1991, 1992; Warrington

\footnotetext{
'Corresponding author.

E-MAIL JANET_WARRINGTON@affymetrix.com; FAX (408) 481-0422.
}

and Bengtsson 1994) from 5q22 to 5q35. An RH map of the Treacher Collins region, 5q31-5q33, placed an additional gene and seven markers. In all, 23 of those gene loci-ADRA1B, ADRB2, ANX6, CD14, CSF1R, DRD1, EGR1, FER, FGF1 (FGFA), FGFR4, FLT4, GABRA1, GABRG2, GLRA1 (GLYA1), GRIA1 (GLUR1), GRL, IL3, IL4, IL9, IL12 (NKSF2), IRF1, RPS14, and SPARC-and seven of those marker loci-D5S119, D5S207, D5S209, D5S210, D5S378, D5S379, and D5S519-are included in the present map. The remaining 14 markers represent seven additional genes- $A P C$, CDC25C, FBN2, F12, MCC, PDE6A, and TCF7and seven DNA markers or sequence-tagged sites (STSs)-D5S22, D5S89, D5S211, LANLSTS129, LANLSTS140, LANLSTS179, and LANLSTS183. Mutations in MCC and APC genes cause colorectal cancers, and FBN2 mutations have been implicated in a Marfan-like syndrome (Groden et al. 1991; Joslyn et al. 1991; Kinzler et al. 1991; Lee et al. 1991; Nishisho et al. 1991). TCF7, PDE6A, F12, and CDC25C encode, respectively, a T-lymphocyte transcription factor, a cGMP phosphodiesterase, human coagulation factor XII, and the human homolog of fission yeast cdc25 (Cool and MacGillivray 1987; Pittler et al. 1990; Sadhu et al. 1990; van der Wetering et al. 1991). Data from our previous maps allowed us to easily place these markers on the RH map using PCR and to construct a contiguous high-resolution 


\section{CHROMOSOME 5 RADIATION HYBRID MAP}

map spanning $-35 \mathrm{Mb}$ of the distal portion of human chromosome 5 .

\section{RESULTS}

The presence or absence of each of the markers in a set of 101 radiation hybrids containing fragments of $5 \mathrm{q}$, described elsewhere (Warrington et al. 1991), was determined by PCR screening. Each of the markers was nonselectively retained in $5 \%-32 \%$ of the hybrids. Retention frequencies of the 28 previously mapped loci ranged from $15 \%$ to $32 \%$ (Warrington et al. 1991, 1992; Loftus et al. 1993; Warrington and Bengtsson 1994). The retention frequencies for the remaining 16 loci are $21 \%, A P C ; 19 \%, C D C 25 C$; 20\%, D5S22; 12\%, D5S89; 15\%, D5S211; 20\%, D5S378; 19\%, D5S379; 16\%, F12; 16\%, MCC; 30\%, PDE6A; 20\%, FBN2; 22\%, LANLSTS129; 15\%, LANLSTS140; 22\%, LANLSTS179; 21\%, LANLSTS183; and 19\%, TCF7. All 44 marker loci were subjected to analyses for order simultaneously, resulting in a very large number of possible orders. Of these orders, 100 have very similar likelihoods with relative likelikhoods under 30 . There are six regions where markers cluster very close together. Four of the clusters consist of single marker pairs, and the remaining two clusters contain three and five markers, respectively. Because there are few breaks between the clustered markers we were unable to determine an unequivocal map order based on this method alone. However, previous mapping efforts using different map assembly methods provide some relative order information for the clusters containing more than two markers. A previously published RH map places FLT4 and DRD1 proximal to FGFR4, and fluorescence in situ hybridization (FISH) mapping places IL4 proximal to IL3 (Warrington et al. 1992; Saltman et al. 1993). For the rest of the map, that is, the markers not included in the six clusters, one order emerged as consistent in the 100 most likely maps and is shown in Figure 1 with the six areas of uncertainty denoted. This map is consistent with a chromosome 5 framework map produced by the $\mathrm{Na}$ - tional Human Genome Research Center (J. McPherson, in prep.).

lod scores of adjacent markers range from 21 to 4 . Distances between adjacent loci are given

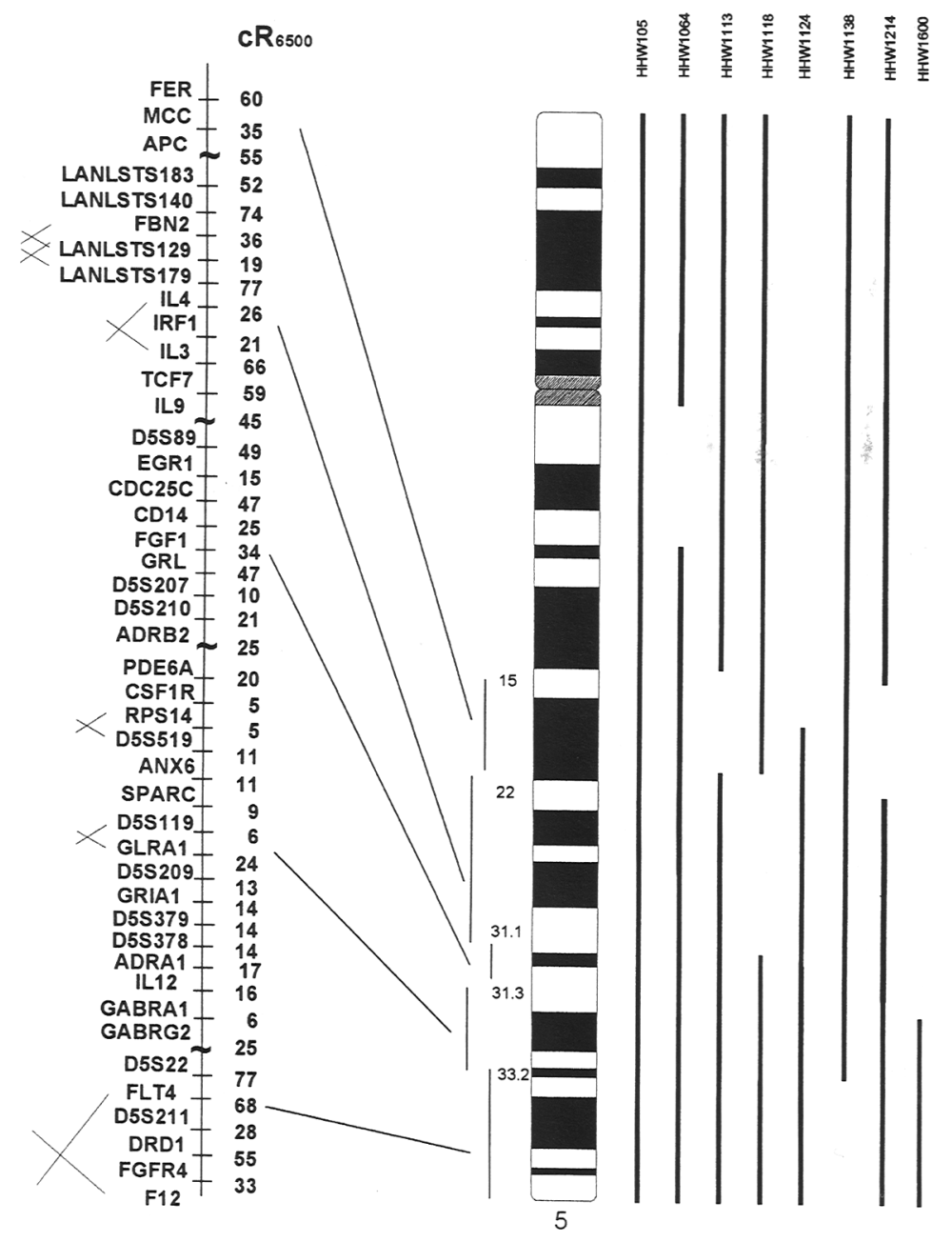

Figure $1 \mathrm{RH}$ map of the distal portion of the long arm of human chromosome 5 aligned with the chromosome 5 natural deletion mapping panel. Marker order is shown on the left with centiray distances between markers. ( ) The breakpoints in the natural deletion panel. The horizontal $X$ to the left of the markers indicates those markers whose order may be inverted. The cytogenetic regions to which sets of markers are assigned are indicated by lines extending to the ideogram. The ideogram depicts a normal chromosome 5 . The bars depict the region of 5 retained in each hybrid cell line. The hybrid HHW105 retains an intact human chromosome 5 as its only human material. The loci FER, MCC, and APC were in all cell lines except HHW1113 (SRO 5q15-5q21). Ten loci (LANLSTS183-IL9) were present in all cell lines except HHW1118 (SRO 5q22-5q31.1). Nine loci (D5S89-ADRB2) were present in all cell lines except HHW1600 (SRO5q31.1-5q31.3). Fourteen loci (PDE6A-GABRG2) were present in all cell lines (SRO 5q31.3$5 q 33.2)$, and six loci (DSS22-F72) were present in all cell lines except HHW1138 (SRO 5q33.3-5qter). 
in RH mapping units, centirays (cR). Distances range from 5 to $77 \mathrm{cR}_{6500}$, with an average distance of $31 \mathrm{cR}_{6500}$ and a median distance of 25 $\mathrm{cR}_{6500}$. The relationship between a $\mathrm{cR}_{6500}$ and actual physical distance in kilobases of DNA for several loci in the q31-q33 region has been determined to be $21 \mathrm{kbp} / \mathrm{cR}$ (Warrington and Bengtsson 1994). Alternatively, an estimate of the distance correlation based on the comparison of the approximate physical distance from $5 \mathrm{q} 21$ to $5 q 35,35 \mathrm{Mbp}$, and the total RH distance of 1369 $\mathrm{cR}_{6500}$, provides an estimate of $26 \mathrm{kbp} / \mathrm{cR}$.

\section{DISCUSSION}

The order of and relative distance between 44 markers on the distal portion of the long arm of human chromosome 5 was determined by $\mathrm{RH}$ mapping. The presence or absence of markers in cell hybrids that retain naturally occuring $5 \mathrm{q}$ deletions helped in ordering the loci. The combination of these methods enabled us to construct a map spanning a physical distance of $\sim 35$ million bp from $5 q 21$ to $5 q 35$, with an average resolution of $-800 \mathrm{~kb}$. If chromosome 5 represents $5 \%$ of the human genome, or $\sim 1.5 \times 10^{8} \mathrm{bp}$, then this 35 $\mathrm{Mb}$ region accounts for nearly $25 \%$ of the chromosome. The newly mapped markers filled two gap regions that were present in previous maps between the markers FER-IL4 and IL3-IL9 (Warrington et al. 1991, 1992). A single marker, TCF7, provided linkage between two markers flanking one of the gaps, IL3 and IL9. The total relative distance for this gap region was $125 \mathrm{cR}_{6500}$, or $\sim 3$ Mbp. The other gap spanned a distance of 243 $\mathrm{cR}_{6500}$, or $\sim 6 \mathrm{Mbp}$, and linkage was obtained with the markers, LANLSTS183, LANLSTS140, FBN2, LANLSTS129, and LANLSTS179. This contiguous high-resolution RH map will be useful for positional cloning efforts and sequence assembly. Establishing the position of genes on the physical map contributes to our understanding of the overall organization of the human genome.

\section{METHODS}

\section{Isolation and Characterization of RHs}

The isolation and characterization of the radiation hybrids has been described (Warrington et al. 1991). The isolation and characterization of human-Chinese hamster ovary (CHO) hybrid HHW661, the irradiated parent of the cell hybrids, has been described by Wasmuth et al. (1986). The
HHW661 cell line retains a derivative human chromosome 5 [der(5)t(5;4)(5qter $\rightarrow 5$ p15.1::4p15.1 $\rightarrow$ 4pter)] as its only detectable human DNA. The nonirradiated Chinese hamster cell parent, UCW113, is an HPRT-deficient derivative of V-79 Chinese hamster lung (CHL) fibroblasts. Irradiation of the cell hybrid and refusion were performed as described previously (Cirullo et al. 1983).

\section{PCR}

The presence or absence of each of the markers in a set 101 radiation hybrids was determined using PCR as described previously (Warrington et al. 1991). Each marker was tested separately; none were multiplexed. The PCR primer sets for $A P C, M C C, F B N 2, T C F 7, P D 6 E A, C D C 25 C, F 12$, and D5S22 were designed from published sequence data and are available in the Genome Database (GDB). PCR conditions for ANX6, GLRA1, FER, IL4, IRF1, IL3, IL9, EGR1, CD14, FGF1, GRL, ADRB2, SPARC, RPS14, CSF1R, GLR1, IL12, GABRA1, GABRG2, FLT4, DRD1, FGFR4, ADRA1B, D5S89, D5S519, D5S378, D5S379, D5S119, D5S207, D5S209, D5S210, and D5S211 have been described (Warrington et al. 1991, 1992; Weber et al. 1991, Ryan et al. 1992b, Dixon et al. 1993, Loftus et al. 1993, Shiang et al. 1993, Nagarajan et al. 1994, Warrington and Bengtsson 1994). Primer sets for LANLSTSS 129, 140,179, and 183 are available in the Genome Sequence Database (GSDB) under numbers L28217, L28223, L28240, and L28242 (Grady et al. 1996). Each PCR was carried out in a total volume of 25 $\mu \mathrm{l}$ using $0.25 \mu \mathrm{g}$ of DNA in $67 \mathrm{~mm}$ Tris- $\mathrm{HCl}(\mathrm{pH} \mathrm{8.3)}, 6.7$ $\mathrm{mM} \mathrm{MgCl}_{2}, 16.6 \mathrm{~mm}$ ammonium sulfate, $10 \mathrm{~mm} \beta$-mercaptoethanol, $1.25 \mathrm{~mm}$ each dNTP, 25 pmoles of each primer, and 1 unit of Thermus aquaticus DNA polymerase.

\section{RH Mapping}

The RH mapping programs RH2PT and RHMAXLIK, version 1.1 (Boehnke et al. 1991; Boehnke 1992) were used to analyze the $\mathrm{RH}$ data. Distances between pairs of loci are reported in $\mathrm{CR}_{6500}$, where 6500 rads indicates the dosage of the X-rays used in the irradiation of the hybrids. Because the $\mathrm{RH}$ map distances stem from the dosage used to fragment the chromosome, it is necessary to note the dosage when reporting distances. The order of the loci was determined by first placing the markers on the cytogenetic map using a natural deletion mapping panel, a panel of five somatic cell hybrids that retain naturally occurring deletions of 5q. Locus ordering by RHMAXLIK was carried out using the stepwise ordering strategy with a machinegenerated candidate order.

\section{ACKNOWLEDGMENTS}

This paper is dedicated to the memory of John J. Wasmuth, friend and mentor. We thank M.A. Spence, R. Shiang, and members of the Wasmuth laboratory for discussions and support. We gratefully acknowledge $\mathrm{M}$. Lovett for cosmid coordinates and PCR primers, and R. White for providing an MCC plasmid for primer development. We thank L. Nagarajan, D. Grady, and R. Moyzis for providing D5S89 primers and LANLSTS primer sets prior to 


\section{CHROMOSOME 5 RADIATION HYBRID MAP}

their publication. We thank Richard Montellano and Rachelle Markovich for excellent technical assistance. J.A.W. was supported by Carcinogenesis Training Grant NCI5T32CA09054-17. This work was supported in part by National Institutes of Health grant HG00320 to J.J.W.

\section{REFERENCES}

Boehnke, M. 1992. Radiation hybrid mapping by minimization of the number of obligate chromosome breaks. Cytogenet. Cell Genet. 59: 96-98.

Boehnke, M., K. Lange, and D.R. Cox. 1991. Statistical methods for multipoint radiation hybrid mapping. Am. J. Hum. Genet. 49: 1174-1188.

Cirullo, R.E., S. Dana, and J.J. Wasmuth. 1983. Efficient procedure for transferring specific human genes into Chinese hamster cell mutants: Interspecific transfer of the human genes encoding leucyl-asparaginyl-tRNA synthetases. Mol. Cell Biol. 3: 892-902.

Cool, D.E. and R.T.A. MacGillivray. 1987.

Characterization of the human blood coagulation factor XII gene. J. Biol. Chem. 262: 13662-13672.

Dixon, M.J., J. Dixon, T. Houseal, T. Bahtt, D.C. Ward, K. Klinger, and G.M. Landes. 1993. Narrowing the position of the Treacher Collins gene to a small interval between three new microsatellite markers on 5q32-33.1. Am. J. Hum. Genet. 52: 907-914.

Grady, D.L., D.L. Robinson, M. Gersh, E. Nickerson, J. McPherson, J.J. Wasmuth, J.O. Overhauser, L.L. Deaven, and R.K. Moyzis. 1996. The generation and regional localization of 303 new chromosome 5 sequence-tagged sites. Genomics 32: 91-96.

Grimaldi, J.C. and T.C. Meeker. 1989. The t(5;14) chromosomal translocation in a case of acute lymphocytic leukemia joins the interleukin 3 gene to the immunoglobulin heavy chain gene. Blood 73: 2081-2085.

Groden, J., A. Thliveris, W. Samowitz, M. Carlson, L. Gelbert, H. Albertsen, G. Joslyn, J. Stevens, L. Spirio, M. Robertson, L. Sargeant, K. Krapcho, E. Wolff, R. Burt, J.P. Hughes, J. Warrington, J. McPherson, J.J. Wasmuth, D. Lepaslier, H. Abderrahim, D. Cohen, M. Leppert, and R. White. 1991. Identification and characterization of the familial adenomatous polyposis-coli gene. Cell 66: $589-600$.

Hästbacka, J., I. Kaitila, P. Sistonen, and A. de la Chapelle. 1990. Diastrophic dysplasia gene maps to the distal long arm of chromosome 5. Proc. Natl. Acad. Sci. 87: 8056-8059.

Huebner, K., M. Isobe, C.M. Croce, D.W. Golde, S.E. Kaufman, and J.C. Gasson. 1985. The human gene encoding GM-CSF is at 5q21-q32, the chromosome region deleted in the $5 \mathrm{q}$ anomaly. Science 230: $1282-1285$.
Jabs, E.W., X. Li, C.A. Coss, E.W. Taylor, D.A. Meyers, and J.L. Weber. 1991. Mapping the Treacher Collins syndrome locus to 5q31.3-q33.3. Genomics 11: 193-198.

Joslyn, G., M. Carlson, A. Thliveris, H. Albertsen, L. Gelbert, W. Samowitz, J. Groden, J. Stevens, L. Spirio, M. Robertson, L. Sargeant, K. Krapcho, E. Wolff, R. Burt, J.P. Hughes, J.A. Warrington, J. McPherson, J.J. Wasmuth, D. Lepaslier, H. Abderrahim, D. Cohen, M. Leppert, and R. White. 1991. Identification of deletion mutations and 3 new genes at the familial polyposis locus. Cell 66: 601-613.

Kinzler, K.W., M.C. Nilbert, B. Vogelstein, T.M. Bryan, D.B. Levy, K.J. Smith, A.C. Preisinger, S.R. Hamilton, P. Hedge, A. Markham, M. Carlson, G. Joslyn, J. Groden, R. White, Y. Miki, Y. Miyoshi, I. Nishisho, and Y. Nakamura. 1991. Identification of a gene located at chromosome $5 \mathrm{q} 21$ that is mutated in colorectal cancers. Science 251: 1366-1370.

Le Beau, M.M., C.A. Westbrook, M.O. Diaz, R.A. Larson, J.D. Rowley, J.C. Gasson, D.W. Golde, and C.J. Sherr. 1986. Evidence for the involvement of GMCSF and FMS in the deletion $5 q$ in myeloid disorders. Science 231: 984-987.

Le Beau, M.M., N.D. Epstein, S.J. O'Brien, A.W. Nienhuis, Y.C. Yang, S.C. Clark, and J.D. Rowley. 1987. The interleukin 3 gene is located on human chromosome 5 and is deleted in myeloid leukemias with a deletion of 5q. Proc. Natl. Acad. Sci. 84: 5913-5917.

Lee, B., M. Godfrey, E. Vitale, H. Hori, M.G. Mattei, M. Sarfarazi, P. Tsipouras, F. Ramirez, and D.W. Hollister. 1991. Linkage of Marfan syndrome and a phenotypically related disorder to 2 different fibrillin genes. Nature 352: $330-334$.

Leon, P.E., H. Raventos, E. Lynch, J. Morrow, and M.C. King. 1992. The gene for an inherited form of deafness maps to chromosome 5q31. Proc. Natl. Acad. Sci. 89: $5181-5184$

Loftus, S.K., S.J. Edwards, T. Scherpbier-Heddema, K.H. Buetow, J.J. Wasmuth, and M.J. Dixon. 1993. A combined genetic and radiation hybrid map surrounding the Treacher Collins syndrome locus on chromosome 5q. Hum. Mol. Genet. 2: 1785-1792.

Muller, U., M.L. Warman, J.B. Mulliken, and J.L. Weber. 1993. Assignment of a gene locus involved in craniosynostosis to chromosome 5qter. Hum. Mol. Genet. 2: $119-122$.

Nagarajan, L., L. Zhao, X. Lu, J.A. Warrington, J.J. Wasmuth, M. Siciliano, A.B. Desseroth, and J.C. Liang. 1994. 5q-Chromosome: Evidence for complex interstitial breaks in a case of refractory anemia with excess blasts. Cancer Genet. Cytogenet. 74: 8-12.

Nishisho, I., Y. Nakamura, Y. Miyoshi, Y. Miki, H. Ando, A. Horii, K. Koyama, J. Utsunomiya, S. Baba, P. Hedge, A. Markham, A.J. Krush, G. Petersen, S.R. Hamilton, 


\section{WARRINGION AND WASMUTH}

M.C. Nilbert, D.B. Levy, T.M. Bryan, A.C. Preisinger, K.J. Smith, L.K. Su, K.W. Kinzler, and B. Vogelstein. 1991. Mutations of chromosome-5q21 genes in fap and colorectal cancer patients. Science 253: 665-669.

Pittler, S.J., W. Baehr, J.J. Wasmuth, D.G. McConnell, M.S. Champagne, P. Vantuinen, D. Ledbetter, and R.L. Davis. 1990. Molecular characterization of human and bovine rod photoreceptor cgmp phosphodiesterase alpha-subunit and chromosomal localization of the human gene. Genomics 6: 272-283.

Ryan, S.G., S.L. Sherman, J.C. Terry, R.S. Sparkes, M.C. Torres, and R.W. Mackey. 1992a. Startle disease or hyperekplexia: Response to clonazepam and assignment of the gene (STHE) to chromosome $5 \mathrm{q}$ by linkage analysis. Ann. Neurol. 31: 663-668.

Ryan, S.G., M.J. Dixon, M.A. Nigro, K.A. Kelts, O.N. Markand, J.C. Terry, R. Shiang, J.J. Wasmuth, and P. O'Connell. 1992b. Gentic and radiation hybrid mapping of the hyperekplexia region on chromosome $5 \mathrm{q}$. Am. J. Hum. Genet. 51: 1334-1343.

Sadhu, K., S.I. Reed, H. Richardson, and P. Russell. 1990. Human homolog of fission yeast cdc 25 mitotic inducer is predominantly expressed in G2. Proc. Natl. Acad. Sci. 87: 5139-5143.

Saltman, D.L., G.M. Dolganov, J.A. Warrington, J.J. Wasmuth, and M. Lovett. 1993. A physical map of 15 loci on human chromosome 5q23-33 by two color fluorescence in situ hybridization. Genomics 16: 726-732.

Shiang, R., S.G. Ryan, Y.-Z. Zhu, A.F. Hahn, P. O'Connell, and J.J. Wasmuth. 1993. Mutations in the $\alpha_{1}$ subunit of the inhibitory glycine receptor cause the dominant neurologic disorder, hyperekplexia. Nature Genet. 5: 351-358.

Speer, M.C., L.H. Yamaoka, J.M. Gilchrist, P.C. Gaskell, J.M. Stajich, J.M. Vance, J.L. Weber, A.D. Roses, and M.A. Pericak-Vance. 1992. Confirmation of genetic heterogeneity in limb-girdle muscular dystrophy: Linkage of an autosomal dominant form to chromosome 5q. Am. J. Hum. Genet. 50: 1211-1217.

Sutherland, G.R., E. Baker, D.F. Callen, H.D. Campbell, I.G. Young, C.J. Sanderson, M. Garson, A.F. Lopez, and M.A. Vadas. 1988. Interleukin 5 is at $5 \mathrm{q} 31$ and is deleted in the 5q syndrome. Blood 71: 1150-1152.

The Treacher Collins Syndrome Collaborative Group. 1996. Positional cloning of the gene involved in the pathogenesis of Treacher Collins syndrome. Nature Genet. 12: 130-136.

van der Wetering, M., M. Oosterwegel, D. Dooijes, and H. Clevers. 1991. Identification and cloning of TCF-1, a T-lymphocyte specific transcription factor containing a sequence-specific HMG box. EMBO J. 10: 123-132.
High-resolution physical mapping of human 5q31-q33 using three methods: Radiation hybrid mapping, interphase fluorescence in situ hybridization, and pulsed-field gel electrophoresis. Genomics 24: 395-398.

Warrington, J.A., L.V. Hall, L.M. Hinton, J.N. Miller, J.J. Wasmuth, and M. Lovett. 1991. Radiation hybrid map of 13 loci on the long arm of chromsome 5. Genomics 11: 701-708.

Warrington, J.A., S.K. Bailey, E. Armstrong, O. Aprelikova, K. Alitalo, G.M. Dolganov, A.S. Wilcox, J.M. Sikela, S.F. Wolfe, M. Lovett, and J.J. Wasmuth. 1992. A radiation hybrid map of 18 growth factor, growth factor receptor, hormone receptor, or neurotransmitter receptor genes on the distal region of the long arm of chromosome 5. Genomics 13: 803-808.

Wasmuth, J.J., L.R. Carlock, B. Smith, and L.L. Immken. 1986. A cell hybrid and recombinant DNA library that facilitate identification of polymorphic loci in the vicinity of the Huntington disease gene. Am. J. Hum. Genet. 39: 397-403.

Weber, J.L., M.H. Polymeropoulos, P.E. May, A.E. Kwitek, H. Xiao, J.D. McPherson, and J.J. Wasmuth. 1991. Mapping of human chromosome 5 microsatellite DNA polymorphisms. Genomics 11: 695-700.

Received March 7, 1996; accepted in revised form May 30, 1996.

Warrington, J.A. and U. Bengtsson. 1994. 


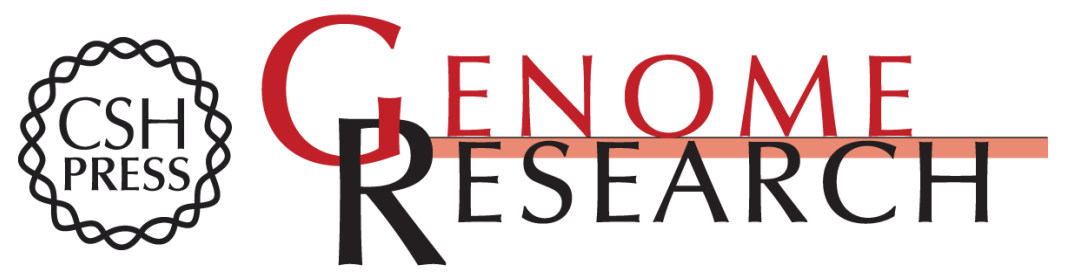

\section{A contiguous high-resolution radiation hybrid map of 44 loci from the distal portion of the long arm of human chromosome 5.}

$\mathrm{J}$ A Warrington and J J Wasmuth

Genome Res. 1996 6: 628-632

Access the most recent version at doi:10.1101/gr.6.7.628

References This article cites 36 articles, 12 of which can be accessed free at:

http://genome.cshlp.org/content/6/7/628.full.html\#ref-list-1

\section{License}

Email Alerting Receive free email alerts when new articles cite this article - sign up in the box at the Service top right corner of the article or click here.

\section{Affordable, Accurate Sequencing.}

To subscribe to Genome Research go to:

https://genome.cshlp.org/subscriptions 